\title{
Effect of biotic elicitors on polyphenol production in Cayratia trifolia cell suspension cultures analyzed by HPLC
}

\author{
Jaya ARora *, ABhishek Joshi, Bhanupriya Kanthaliya, Farhana KhaN
}

Laboratory of Biomolecular Technology, Department of Botany, Mohanlal Sukhadia University, Udaipur 313001, Rajasthan, India

\begin{abstract}
Cayratia trifolia Linn. Domin Syn. Vitis trifolia (family: Vitaceae) contains polyphenols as major bioactive compounds. Plant polyphenolics, such as stilbenes, possess a broad spectrum of pharmacological and therapeutic effects, including antioxidative, anticancerous, antiatherosclerotic, cardioprotective, hepatoprotective, and neuroprotective effects. Elicitation is one of the important strategies to enhance secondary metabolite production in cell suspension cultures. In the present study, the effect of two biotic elicitors, namely one fungal (Fusarium sp., and Helminthosporium sp.) extract and another higher plant-originated gum (Anogeissus latifolia), was evaluated for enhanced production of stilbenes in cell suspension culture of $C$. trifolia. For the fungal elicitor, the cell suspension cultures of $C$. trifolia were treated with varying concentrations of Fusarium extract (FE) and Helminthosporium extract (HE) on the $7^{\text {th }}$ day of culture. Increasing concentration of $\mathrm{FE}$ in the medium resulted in slightly decreased cell growth but increased the production of stilbenes, with the optimal concentration at $1000 \mathrm{mg} / \mathrm{l}$. This increase in the yield of stilbenes was $\sim 5$ times $(9.30 \mathrm{mg} / \mathrm{l})$ higher than the control value. HE was less effective than $\mathrm{FE}$ in increasing stilbene production at optimal concentrations. The addition of $50 \mathrm{mg} / \mathrm{l}$ A. latifolia plant gum sieved through a 150 mesh $(0.1 \mathrm{~mm})$ to $C$. trifolia cell culture enhanced stilbene accumulation and yield by 8 - to 9 -fold over the control value.
\end{abstract}

Key words: Cayratia trifolia, fungal elicitors, gum, suspension culture

\section{Introduction}

The term phytoalexin (from the Greek word phyton meaning "plant" and alexein meaning "to defend") was first proposed by Müller and Börger (1940) in their hypothesis that defense responses in plants (potato) could be activated after infection with fungi (Phytophthora infestans). The NATO Advanced Study Institute on "Active Defense Mechanisms in Plants” (Paxton, 1981) defined phytoalexin as "low molecular weight antimicrobial compounds that are both synthesized by and accumulated in plants after exposure to microorganisms." Phytoalexins have received much attention over the past 70 years, and much of this work has provided new insights on gene regulation and phytochemical diversity specially related to secondary metabolites. Elicitors are physical or chemical factors that trigger morphological and physiological responses such as phytoalexin accumulation when they come in contact with living plant cell systems. Elicitors are either biotic or abiotic in origin. Abiotic elicitors are substances of non biological origin such as organic salts and physical factors (Angelova et al., 2006). Biotic elicitors are substances with biological origin, e.g., extracts of pathogenic microorganisms (chitins and glucans), enzymes such as cellulase or pectinase, and plant gums and glycoproteins,whose functions are coupled to receptors and act by activating or inactivating a number of enzymes or ion channels (Goyal et al., 2012). The interaction of any of these components with the plant cells induces numerous defense responses, which include the production of phytoalexins, pathogenesis-related proteins, protease inhibitors, and a variety of other defense compounds (Arora et al., 2012).Recent studies have shown that appropriate biochemical treatment and manipulation (e.g., elicitors and precursors) can result

\footnotetext{
* Corresponding author: Laboratory of Biomolecular Technology, Department of Botany, Mohanlal Sukhadia University, Udaipur 313001, Rajasthan, India; email: jaya890@gmail.com
} 
in an increase in the production of some secondary compounds and accumulation of chemicals that would not normally be synthesized in the source plants (Giri and Zaheer, 2016; Naik and Al-Khayri, 2016). Responses induced by plant oligosaccharides include stem elongation, stimulation of ethylene production, auxin antagonization, and elicitation of various defensive actions. The structurally defined fragments of plant cell wall polysaccharides can also function in plant cell/tissue culture as chemical messages with specific regulatory properties (Winkler et al., 2017; Xu et al., 2017). Biotic elicitors such as chitosan and its oligomers obtained from fungal cell wall (Katiyar et al., 2015) and plant gums (Dass and Ramawat, 2009) have shown strong elicitation effect in cell cultures for the production of secondary metabolites. Previous studies have reported increased production of indole alkaloids in cell suspension cultures of Catharanthus roseus (Liang et al., 2018; Sharma et al., 2019) and taxol and related taxanes in suspension cultures of Taxus sp. (Vidal-Limon et al., 2016; Sarmadi et al., 2018). Among abiotic elicitors, salicylic acid (SA) and methyl jasmonate (MeJa) induced high accumulation of isoflavonoids in cell cultures of Pueraria tuberosa (Goyal and Ramawat, 2008), and stilbenes in cell cultures of C. trifolia (Roat and Ramawat, 2009a). According to Ramirez-Estrada et al. (2016), elicitors have different mechanisms of elicitation, and when used in combination, they synergistically enhance metabolite production in cultured plant cells. Enhancement of secondary metabolites by elicitation is one of the few strategies that has recently found commercial applications such as production of pharmaceuticals, insecticides, flavoring agents, drugs (morphine, codeine, cocaine, quinine, etc.), and many other important biochemicals (Silpa et al., 2018). We have previously reported the production of stilbenes stimulated by elicitors (Roat and Ramawat, 2009a) and by plant growth regulators in cell cultures (Roat and Ramawat, 2009b) and root cultures (Arora et al., 2009) of $C$. trifolia. In the present study, we report enhanced production of stilbenes in $C$. trifolia cell cultures through the use of two biotic elicitors (fungal and gum).

\section{Materials and methods}

\section{Cell cultures and experimental setup}

Cell suspension culture were initiated from 4-weekold callus (grown from $C$. trifolia leaf explants) by trans- ferring $2 \mathrm{~g}$ friable cream colored callus into $250 \mathrm{ml}$ Erlenmeyer flask containing $50 \mathrm{ml}$ of liquid MS basal medium (Murashige and Skoog, 1962) supplemented with 2,4 -D at $0.25 \mathrm{mg} / \mathrm{l}, \mathrm{NAA}$ at $0.2 \mathrm{mg} / \mathrm{l}$, kinetin at $0.2 \mathrm{mg} / \mathrm{l}$, and casein hydrolysate at $250 \mathrm{mg} / \mathrm{l}$ with the addition of 3\% w/v sucrose. Subsequently, 2,4-D was removed from the medium, and the cultures were maintained in MS basal medium supplemented with NAA at $0.25 \mathrm{mg} / \mathrm{l}$ and kinetin at $0.2 \mathrm{mg} / \mathrm{l}$ (growth medium). Subcultures were performed at every $15^{\text {th }}$ day by transferring $15 \mathrm{ml}(\sim 125 \mathrm{mg}$ dry mass (DM)) of the culture into $85 \mathrm{ml}$ of fresh medium. The cultures were grown in dark at $25^{\circ} \mathrm{C}$ on an orbital shaker at $100 \mathrm{rpm}$.

\section{Effect of fungal elicitor}

Cell cultures were treated with dried powder of fungal cell wall obtained from autoclaved cultures of two fungal species (Fusarium species and Helminthosporium species). Different concentrations (50, 100, 200, 500,1000 , and $2000 \mathrm{mg} / \mathrm{l}$ ) of autoclaved aqueous suspensions were added to the medium on the $7^{\text {th }}$ day of culture. These suspensions were Fusarium extract (FE) and Helminthosporium extract (HE). Time course study was performed for cell growth and stilbene production.

\section{Effect of gum polysaccharides as elicitor}

Gum samples obtained from Anogeissu slatifolia (gum ghatti) were grinded in a mortar and strained through two different sized sieves $(0.4 \mathrm{~mm}, 40$ mesh and $0.1 \mathrm{~mm}, 150$ mesh; Sigma Co., USA). Fatty acids and pigments were extracted overnight from the gum by using chloroform. Chloroform was then removed by filtration. Polyphenol and low-molecular-weight compounds were extracted from the residues with methanol several times until a colorless extract was obtained. After filtration, the residue was washed thrice in ice-cold water. The gum powder $(50,150$, and $300 \mathrm{mg} / \mathrm{l})$ thus obtained was added to the growth medium on the $7^{\text {th }}$ day of culture, and the cells were harvested on the $15^{\text {th }}$ day of culture.

\section{Growth determination}

The cells were harvested after 15 days by vacuum filtration, rapidly washed with cold distilled water, and weighed to obtain fresh mass per $100 \mathrm{ml}$ medium. DM was then determined by drying the cells at $60^{\circ} \mathrm{C}$ in an oven until a constant weight was obtained. 


\section{Determination of Stilbene content by HPLC}

The cell cultures were harvested, washed with distilled water, and filtered under mild vacuum. Dried homogenized cells $(50 \mathrm{mg})$ were extracted in acetone-water $(3: 2(\mathrm{v} / \mathrm{v}))$ for $12 \mathrm{~h}$ (ambient temperature) on a test tube rotator and centrifuged at $2000 \mathrm{rpm}$ for $15 \mathrm{~min}$, and the supernatant was then concentrated under vacuum at $40^{\circ} \mathrm{C}$ until the complete removal of acetone. The aqueous extract was then partitioned twice with an equal amount of ethyl acetate. Finally, the ethyl acetate phase was concentrated under vacuum till dryness. This extract was re-dissolved in HPLC-grade methanol, filtered, and analyzed by HPLC (pump L2130, autosampler L-2200, FL detector L-2485, Merck-Hitachi). Separation was accomplished on a (LichroCART) ${ }^{\circledR} 250 \times 4 \mathrm{~mm}$ Purospher ${ }^{\circledR}(5 \mathrm{~mm})$ RP-18 column protected by a guard column of the same material. The solvent system used was as follows: Solvent A- $0.0025 \%$ TFA in water; solvent B- $80 \%$ ACN (E. Merck, India) in solvent A. The mobile phase consisted of solvent A and solvent $B$. The step gradient program of solvent $B$ was as follows: $0-3 \mathrm{~min}$, 14\%-18\%; 3-12 min, $18 \%-18 \%$; $12-25$ min, $18 \%-22 \%$; 25-30 min, 22\%-22\%; 30-38 min, 22\%-40\%; 38-43 min, $40 \%-40 \%$; 43-46 min, 40\%-60\%; 46-48 min, 60\%-70\%; 48-50 min, 70\%-70\%; 50-52 min, 70\%-80\%; 52-54 min, 80\%-80\%; 54-56 min, 80\%-85\%; 56-58 min, 85\%-100\%; 58-60 min: $100 \%-100 \%$; 60-62 min, $100 \%-14 \%$; 62-65 min, $14 \%-14 \%$. Separation+ was performed at a flow rate of $1.0 \mathrm{ml} / \mathrm{min}$, and chromatographic peaks were monitored at $\lambda$ exc $300 \mathrm{~nm}$ and $\lambda$ em $390 \mathrm{~nm}$ (Krisa et al., 1999). Standard compound trans-resveratrol (3,5,4'-trihydroxystilbene) was purchased from $\mathrm{Si}$ gma Chemical Co. (St. Louis, MO, USA), and transpiceid (3,3,4,5'-tetrahydro-xystilbene), trans-e-viniferin, and ampelopsin A were kindly provided by Prof. J.M. Merillon, France. Standard compounds were dissolved in methanol to yield a final concentration of $1.0 \mathrm{mg} / \mathrm{l}$, and a standard curve was prepared using resveratrol with concentrations ranging from 50 to $500 \mathrm{ng} / \mathrm{ml}$. The amount of the other compounds was calculated on the basis of trans-resveratrol. The results of stilbenes are expressed as $\mu \mathrm{g} / \mathrm{g}$ cell DM.

\section{Statistical analysis}

All results were averaged over two separate analyses for stilbene estimation, and two consecutive laboratory experiments with six replicate flasks for each treatment were performed for growth value determination. For growth and individual stilbene concentration, the data were analyzed by ANOVA followed by Dunnett's multiple comparison test (comparing all versus control) using Prism statistical software. Mean values were considered statistically significantly at $P \leq 0.05$ when compared with control.

\section{Results}

\section{Effect of fungal elicitors}

\section{Time course for stilbene induction}

The results for the time course experiments for the induction of stilbenes in cultures treated with $200 \mathrm{mg} / \mathrm{l}$ of $\mathrm{FE}$ and $\mathrm{HE}$ are presented in Table 1. In the cultures treated with $200 \mathrm{mg} / 1 \mathrm{FE}$ added on the $7^{\text {th }}$ day of culture, maximum concentrations of piceid $(67.8 \mu \mathrm{g} / \mathrm{g})$, resveratrol $(76.0 \mu \mathrm{g} / \mathrm{g})$, and ampelopsin $(433.1 \mu \mathrm{g} / \mathrm{g})$ were recorded, while viniferin $(82.8 \mu \mathrm{g} / \mathrm{g})$ concentration was decreased when compared with control conditions. The concentration of stilbenes decreased when FE was added at the $10^{\text {th }}$ and $12^{\text {th }}$ day of culture; however, except for viniferin, it remained higher than the control value. The cultures accumulated maximum total stilbenes $(659.8 \mu \mathrm{g} / \mathrm{g})$ on the $7^{\text {th }}$ day of treatment with a yield of $5.2 \mathrm{mg} / \mathrm{l}$ (Table 1). On the basis of these results, different concentrations $(50,100,200,500,1000$, and $2000 \mathrm{mg} / \mathrm{l}$ ) of FE were added on the $7^{\text {th }}$ day of culture to obtain effective concentration of $\mathrm{FE}$ for increased accumulation of stilbenes. In the cultures treated with $200 \mathrm{mg} / \mathrm{l} \mathrm{HE}$, added on the $7^{\text {th }}$ day of culture, maximum concentrations of piceid $(16.6 \mu \mathrm{g} / \mathrm{g})$, viniferin $(169.0 \mu \mathrm{g} / \mathrm{g})$, and ampelopsin $(326.3 \mu \mathrm{g} / \mathrm{g})$ were recorded as compared to control conditions, while the maximum concentration of resveratrol $(95.8 \mu \mathrm{g} / \mathrm{g})$ was recorded when HE was added on the $10^{\text {th }}$ day of culture. The concentrations of all stilbenes decreased when HE was added on the $10^{\text {th }}$ and the $12^{\text {th }}$ day of culture as compared to that when added on the $7^{\text {th }}$ day; however, except for resveratrol, it remained higher than the control value. The cultures accumulated maximum total stilbenes $(540.3 \mu \mathrm{g} / \mathrm{g})$ on the $7^{\text {th }}$ day of treatment with a yield of $4.2 \mathrm{mg} / \mathrm{l}$ (Table 1). On the basis of these results, different concentrations of $\mathrm{HE}$ were added on the $7^{\text {th }}$ day of culture to obtain effective concentration of $\mathrm{HE}$ for increased accumulation of stilbenes. An authentic 
Table 1. Time course of cell growth and stilbene production in $C$. trifolia cell culture grown in $250 \mathrm{ml}$ flasks in growth medium elicited with fungal elicitor

\begin{tabular}{|c|c|c|c|c|c|c|c|c|}
\hline \multirow{3}{*}{$\begin{array}{l}\text { Fungal elicitor } \\
\text { [200 mg/l] }\end{array}$} & \multirow{2}{*}{$\begin{array}{c}\text { Day } \\
\text { of addition }\end{array}$} & \multirow{2}{*}{$\begin{array}{l}\mathrm{DM} \\
{[\mathrm{g} / \mathrm{l}]}\end{array}$} & \multicolumn{5}{|c|}{ Stilbene concentration $\mu \mathrm{g} / \mathrm{g} \mathrm{DM} \pm \mathrm{SD}$} & \multirow{2}{*}{$\begin{array}{l}\text { Yield } \\
{[\mathrm{mg} / \mathrm{l}]}\end{array}$} \\
\hline & & & piceid & resveratrol & viniferin & ampelopsin & total & \\
\hline & control & 8.1 & $12 \pm 1.1$ & $26.1 \pm 1.8$ & $159.0 \pm 9.0$ & $50.0 \pm 4.8$ & 248.4 & 2.0 \\
\hline \multirow{3}{*}{ Fusarium extract } & $7^{\text {th }}$ day & 7.9 & $67.8 \pm 4.5$ & $76.0 \pm 4.8$ & $82.8 \pm 4.9$ & $433.1 \pm 22.5$ & 659.8 & 5.2 \\
\hline & $10^{\text {th }}$ day & 8.0 & $51.2 \pm 3.5$ & $45.9 \pm 3.5$ & $50.2 \pm 2.5$ & $357.6 \pm 18.9$ & 504.9 & 4.0 \\
\hline & $12^{\text {th }}$ day & 8.0 & $48.2 \pm 2.5$ & $37.1 \pm 2.8$ & $91.1 \pm 4.6$ & $161.7 \pm 7.6$ & 373.9 & 2.9 \\
\hline \multirow{3}{*}{$\begin{array}{l}\text { Helminthosporium } \\
\text { extract }\end{array}$} & $7^{\text {th }}$ day & 7.8 & $16.6 \pm 1.4$ & $28.4 \pm 1.6$ & $169.0 \pm 6.2$ & $326.3 \pm 27.3$ & 540.3 & 4.2 \\
\hline & $10^{\text {th }}$ day & 7.9 & $10.4 \pm 1.2$ & $95.8 \pm 3.2$ & $104.1 \pm 5.1$ & $240.3 \pm 20.5$ & 450.6 & 3.6 \\
\hline & $12^{\text {th }}$ day & 8.0 & $9.8 \pm 1.3$ & $53.1 \pm 2.3$ & $90.6 \pm 4.5$ & $262.7 \pm 12.1$ & 416.2 & 3.3 \\
\hline
\end{tabular}

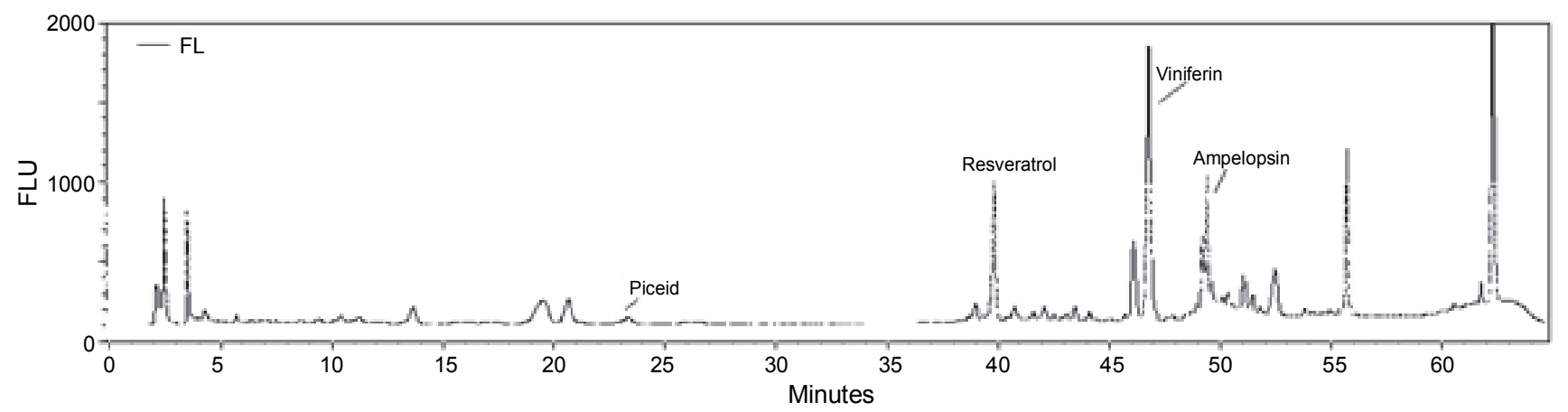

Fig. 1. HPLC chromatogram showing four important stilbenes, namely piceid, resveratrol, viniferin, and ampelopsin, for reference

chromatogram showing four important stilbenes, namely piceid, resveratrol, viniferin, and ampelopsin, is given for reference (Fig. 1).

\section{Effect on stilbenes production by different concentrations of $\mathrm{FE}$ and $\mathrm{HE}$}

The cell suspension cultures of $C$. trifolia were treated with varying concentrations of $\mathrm{FE}$ and $\mathrm{HE}$ on the $7^{\text {th }}$ day of culture (Table 2 and Table 3). Increasing concentration of $\mathrm{FE}$ in the medium resulted in slightly decreased growth of the cells (Table 2), while the increasing concentration of elicitor effectively increased stilbene productionin the medium, with the optimal concentration at $1000 \mathrm{mg} / \mathrm{l}$. This increase in the yield of stilbenes was $\sim 5$ times $(9.30 \mathrm{mg} / \mathrm{l})$ higher than the control value $(2.01 \mathrm{mg} / \mathrm{l})$. With further increase in the concentration to $2000 \mathrm{mg} / \mathrm{l}$, the total yield of stilbenes was $7 \mathrm{mg} / \mathrm{l}$, which was also significantly higher than the control value. Therefore, it was concluded that $\mathrm{FE}$ can be used as a triggering agent for stilbene induction at the onset of stationary phase cultures. The concentrations of piceid (147.2 $\mu \mathrm{g} / \mathrm{g})$, resveratrol (137.5 $\mu \mathrm{g} / \mathrm{g})$, and ampelopsin $(843.7 \mu \mathrm{g} / \mathrm{g})$ showed a marked increase as compared to the control value with increasing concentration of FE up to $1000 \mathrm{mg} / \mathrm{l}$, while viniferin concentration showed a gradual decrease with increasing concentration of $\mathrm{FE}$ as compared to the control value. Because viniferin is known to be a dimmer of resveratrol (Pezet et al., 2003), its decrease is correlated with the increase in resveratrol concentration. When $\mathrm{HE}$ was added to cell cultures in increasing concentration, a trend similar to that of $\mathrm{FE}$ was observed in terms of cell growth and stilbene production, but overall $\mathrm{HE}$ was less effective than FE at the optimal concentration (Table 3). Resveratrol $(138.5 \mu \mathrm{g} / \mathrm{g})$ and viniferin $(820.6 \mu \mathrm{g} / \mathrm{g})$ concentrations increased with an increase in $\mathrm{HE}$ concentration up to $2000 \mathrm{mg} / \mathrm{l}$, while the maximum concentrations of piceid $(23.3 \mu \mathrm{g} / \mathrm{g})$ and ampelopsin $(326.6 \mu \mathrm{g} / \mathrm{g})$ were obtained at 500 and $200 \mathrm{mg} / \mathrm{l} \mathrm{HE}$ concentrations, respectively. 
Table 2. Effect of fungal elicitor (Fusarium extract, added on the $7^{\text {th }}$ day) on cell growth and stilbene accumulation in $C$. trifolia cell cultures grown in $250 \mathrm{ml}$ flasks in growth medium; the data were analyzed by one-way ANOVA followed by Dunnett's multiple comparison test (comparing all versus control)

\begin{tabular}{|c|c|c|c|c|c|c|c|}
\hline \multirow{2}{*}{$\begin{array}{c}\text { Fungal elicitor } \\
{[\mathrm{mg} / \mathrm{l}]}\end{array}$} & \multirow{2}{*}{$\begin{array}{l}\mathrm{DM} \\
{[\mathrm{g} / \mathrm{l}]}\end{array}$} & \multicolumn{5}{|c|}{ Stilbene concentration $\mu \mathrm{g} / \mathrm{g} \mathrm{DM} \pm \mathrm{SD}$} & \multirow{2}{*}{$\begin{array}{l}\text { Yield } \\
{[\mathrm{mg} / \mathrm{l}]}\end{array}$} \\
\hline & & piceid & resveratrol & viniferin & ampelopsin & total & \\
\hline Control & 8.1 & $12 \pm 1.1$ & $26.1 \pm 1.8$ & $159.0 \pm 9.0$ & $50.0 \pm 4.8$ & 248.4 & 2.01 \\
\hline 50 & 8.1 & $22.9^{\mathrm{d}} \pm 1.4$ & $32.5^{\mathrm{c}} \pm 1.8$ & $143.8^{\mathrm{c}} \pm 6.1$ & $163.1^{\mathrm{d}} \pm 7.1$ & $362.3^{\mathrm{c}}$ & 2.93 \\
\hline 100 & $7.9^{\mathrm{d}}$ & $35.1^{\mathrm{d}} \pm 2.3$ & $35.43^{c} \pm 5.7$ & $133.7^{\mathrm{d}} \pm 5.8$ & $399.0^{\mathrm{d}} \pm 22.8$ & $603.3^{d}$ & 4.77 \\
\hline 200 & $7.9^{\mathrm{d}}$ & $67.8^{\mathrm{d}} \pm 4.3$ & $76.0^{\mathrm{d}} \pm 6.2$ & $122.0^{\mathrm{d}} \pm 5.4$ & $433.2^{\mathrm{d}} \pm 22.1$ & $699.0^{\mathrm{d}}$ & 5.52 \\
\hline 500 & $7.8^{\mathrm{d}}$ & $120.7^{\mathrm{d}} \pm 2.3$ & $101.5^{\mathrm{d}} \pm 5.3$ & $112.0^{\mathrm{d}} \pm 5.1$ & $444.4^{\mathrm{d}} \pm 23.2$ & $778.9^{\mathrm{d}}$ & 6.08 \\
\hline 1000 & $7.7^{d}$ & $147.2^{\mathrm{d}} \pm 6.2$ & $137.5^{\mathrm{d}} \pm 4.2$ & $80.1^{\mathrm{d}} \pm 2.3$ & $843.7^{\mathrm{d}} \pm 38.2$ & $1208.4^{\mathrm{d}}$ & 9.30 \\
\hline 2000 & $7.6^{d}$ & $24.7^{\mathrm{d}} \pm 1.4$ & $100.2^{\mathrm{d}} \pm 4.1$ & $70.8^{\mathrm{d}} \pm 5.6$ & $726.5^{\mathrm{d}} \pm 25.4$ & $922.2^{\mathrm{d}}$ & 7.00 \\
\hline$F$-value & $26.9^{b}$ & $813^{b}$ & $274^{\mathrm{b}}$ & $90.5^{b}$ & $512^{b}$ & $229.3^{b}$ & \\
\hline
\end{tabular}

a - non significant $(P>0.05), \mathrm{b}$ - significant $(P<0.01)$, $\mathrm{c}$ or $\mathrm{d}-$ mean values are significantly different when compared with control at $(P<0.05)$ or $(P<0.01)$, according to Dunnett's multiple comparison test; mean data without footnote label are non significantly different from the control value

Table 3. Effect of fungal elicitor (Helminthosporium extract, added $7^{\text {th }}$ day) on cell growth and stilbene accumulation in $C$. trifolia cell cultures grown in $250 \mathrm{ml}$ flasks in growth medium; the data were analyzed by one-way ANOVA followed by Dunnett's multiple comparison test (comparing all versus control)

\begin{tabular}{|c|c|c|c|c|c|c|c|}
\hline \multirow{2}{*}{$\begin{array}{l}\text { Fungal elicitor } \\
{[\mathrm{mg} / \mathrm{l}]}\end{array}$} & \multirow{2}{*}{$\begin{array}{l}\mathrm{DM} \\
{[\mathrm{g} / \mathrm{l}]}\end{array}$} & \multicolumn{5}{|c|}{ Stilbene concentration $\mu \mathrm{g} / \mathrm{g} \mathrm{DM} \pm \mathrm{SD}$} & \multirow{2}{*}{$\begin{array}{l}\text { Yield } \\
{[\mathrm{mg} / \mathrm{l}]}\end{array}$} \\
\hline & & piceid & resveratrol & viniferin & ampelopsin & total & \\
\hline Control & 8.1 & $12.0 \pm 1.2$ & $26.1 \pm 1.9$ & $159.0 \pm 7.1$ & $50.0 \pm 4.8$ & 248.4 & 2.01 \\
\hline 200 & 8.0 & $16.6^{\mathrm{d}} \pm 1.4$ & $28.4 \pm 1.6$ & $169.0 \pm 6.2$ & $326.3^{\mathrm{d}} \pm 27.3$ & $540.3^{\mathrm{d}}$ & 4.32 \\
\hline 500 & $7.9^{\mathrm{d}}$ & $23.3^{\mathrm{d}} \pm 1.8$ & $102.9^{\mathrm{d}} \pm 5.1$ & $410.8^{\mathrm{d}} \pm 25.5$ & $164.4^{\mathrm{d}} \pm 6.3$ & $701.5^{\mathrm{d}}$ & 5.54 \\
\hline 1000 & $7.8^{\mathrm{d}}$ & $17.3^{\mathrm{d}} \pm 1.6$ & $109.9^{\mathrm{d}} \pm 5.8$ & $661.5^{\mathrm{d}} \pm 35.6$ & $92.1^{\mathrm{d}} \pm 4.2$ & $834.8^{\mathrm{d}}$ & 6.51 \\
\hline 2000 & $7.7^{\mathrm{d}}$ & $13.9 \pm 1.1$ & $138.5^{\mathrm{d}} \pm 6.3$ & $820.6^{\mathrm{d}} \pm 43.3$ & $30.9 \pm 2.1$ & $1003.9^{d}$ & 7.73 \\
\hline$F$-value & $39.5^{b}$ & $26.6^{\mathrm{b}}$ & $477^{\mathrm{b}}$ & $335^{b}$ & $259^{b}$ & $206^{\mathrm{b}}$ & \\
\hline
\end{tabular}

a - non significant $(P>0.05), \mathrm{b}$ - significant $(P<0.01)$, c or $\mathrm{d}-$ mean values are significantly different when compared with control at $(P<0.05)$ or $(P<0.01)$, according to Dunnett's multiple comparison test; mean data without footnote label are non significantly different from the control value

\section{Discussion}

Elicitors of fungal origin have been widely used to increase natural product formation in plant cell culture, and this strategy has been effective in stimulating the production of many chemical classes of secondary metabolites, such as terpenoids, coumarin derivatives, alkaloids, and flavonoids (Espinosa-Leal et al., 2018; Salehi et al., 2018). When grapevine experiences biotic stress, stilbenes act as phytoalexins. Grey mold (Botrytis cinerea Pers.), downy mildew (Plasmoparaviticola Berk.), berry rot (Rhizopusstolonifer Ehrenb. Fr. Lind), and some Aspergillus spp. are some of the main fungi that attack the grapevine and lead to the production of transresveratrol, $\varepsilon$-viniferin, $\alpha$-viniferin, $\delta$-viniferin, pterostilbene, and piceatannol, in both grape berries and leaves (Saigne-Soulard et al., 2015). In Linum album hairy roots fungal elicitation causedan increase in the levels of amino acids, phenolic compounds, and lignin (Tashackori et al., 2019). Chitosan and salicylic acid enhanced biomass accumulation and polyphenols in callus cultures of Fagoniaindica (Khan et al., 2019). The endophytic fungal elicitor has also been shown to increase the expression of specific genes in medicinal plants, which can result in enhanced accumulation of bioactive molecules by 
the activation of a series of specific secondary metabolic pathways (Zhai et al., 2017). Various strategies using fungal elicitors for enhancing the production of secondary metabolites have been briefly described by Shasmita et al. (2018) and Baldi et al. (2009). The fungal elicitor Aspergillus flavus enhanced the total indole alkaloid production of Catharanthusroseus cambial meristematic cell cultures. Transcriptome analysis of such cultures showed increased expression of various genes of the biosynthetic pathway of indole alkaloids (Liang et al., 2018). Various signaling pathways and their receptors such as avirulent determinants and corresponding plant $\mathrm{R}$ proteins; heterotrimeric and small GTP binding proteins; ion fluxes, especially $\mathrm{Ca}^{2+}$ influx, and $\mathrm{Ca}^{2+}$ signaling are regulated by elicitors for enhanced production of secondary metabolites (Zhao et al., 2005).

In the present study, a 5-fold increase in total stilbene production by cell suspension culture in the presence of fungal elicitors was significant and can be used in combination with other PGRs, sucrose, and precursors, to further enhance stilbene production. Attempts were made to grow cells with all elicitors in shake flasks and bioreactor (Goyal and Ramawat, 2008a). Significant effects of fungal elicitors on stilbene production and accumulation in plant cell cultures were demonstrated in this work. This effect of biotic elicitors can be further investigated for the high yield of secondary metabolites in a short time in bioreactors. Reduction in time and increase in production have significant effects on cost effectiveness.

\section{Gum polysaccharides as elicitors}

The results obtained with gum ghatti are presented in Figure 2. In the treatment, the following two parameters were measured: 1) effect of gum polysaccharides (50-300 mg/l) as elicitor and, 2) effect of particle size of gum (strained through two different sized sieves: $0.4 \mathrm{~mm}$, 40 mesh and $0.1 \mathrm{~mm}, 150$ mesh) on stilbene production. All three concentrations of the elicitor did not alter the growth of $C$. trifolia cells; however, stilbene accumulation and yield was enhanced by 8 - to 9 -fold over the control. Gum ghatti at $50 \mathrm{mg} / \mathrm{l}$ concentration was most effective in enhancing stilbene accumulation $(7.2 \mathrm{mg} / \mathrm{l})$, followed by the concentrations of $150(3.44 \mathrm{mg} / 1$ stilbene) and $300 \mathrm{mg} / 1$ ( $2.77 \mathrm{mg} / \mathrm{l}$ stilbene $)$ in the medium in both particle sizes. Gum resin production is a stressinduced phenomenon, and high yields are obtained du- ring pathogenesis abiotic and biotic stress. Plant gums, especially gum ghatti, is a complex mixture of polysaccharides and arabinogalactan proteins (Pal, 2008; Kora et al., 2012). Several types of gelling agents including plant gums have been used in plant tissue culture (Jain et al., 2005), but their role as elicitors has been demonstrated only in Commiphora wightii (Das and Ramawat, 2009). Failure of higher concentrations of the used gum to elicit higherstilbene accumulation may be explained on the basis of oxidative stress due to $\mathrm{H}_{2} \mathrm{O}_{2}$ production, leading to cell death (Yu et al., 2002). When the gum was strained through 150 mesh metal sieves and added to the cell culture, it was more effective in stimulating stilbene production than gum strained through 40 mesh metal sieves (Fig. 2) as particle with smaller sizes have more contact with cell surface. The problem of size effect on cell uptake of nanoparticles is currently an important issue in the field of nanobiology, and it has been shown in various drug delivery systems that particle size, shape, and surface charge affect the cellular uptake of particular compounds (He et al., 2010; Kulkarni and Feng, 2013; Zheng and $\mathrm{Yu}, 2016$ )

It has been found that particle size can affect the efficiency and pathway of cellular uptake by influencing the adhesion of the particles and their interaction with cells. However, many factors, such as surface chemistry, ion charge, and size of the elicitor compound affect its uptake (Lu et al., 2009; He et al., 2010). The use of gum as an elicitor is a new concept (Dass and Ramawat, 2009). In C. trifolia cell cultures, gum ghatti stimulated higher stilbene accumulation at lower concentrations; hence, it could be used in combination with precursors (Phenyl ammonia lyase, cinnamic acid etc.) and different abiotic elicitors for further enhanced accumulation of stilbenes as a cost-effective system. Because gum is effective at small particle sizes, it can be used at nano sizes, which could open new possibilities in secondary metabolite production through cell suspension cultures, as the concept can be used with other biotic and abiotic elicitors. Treatment with biotic and abiotic elicitors can be an effective strategy to increase the yield of specific metabolites obtained from $C$. trifolia cell cultures. Understanding how plant cells perceive these elicitors and how this perception leads to the accumulation of secondary metabolites may help us to improve the production of stilbenes in terms of quantity and quality of the compounds. The knowledge gathered in the past 
A

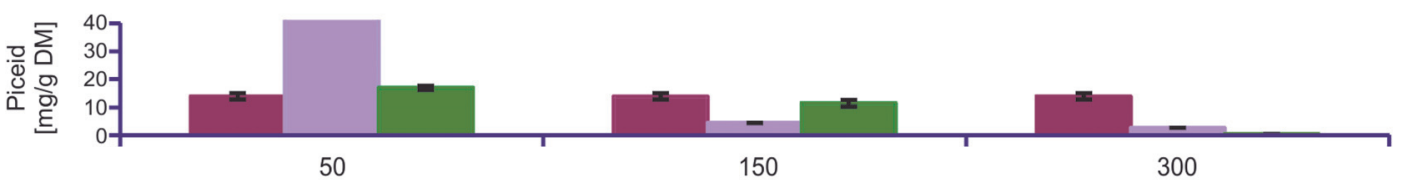

$\mathrm{B}$

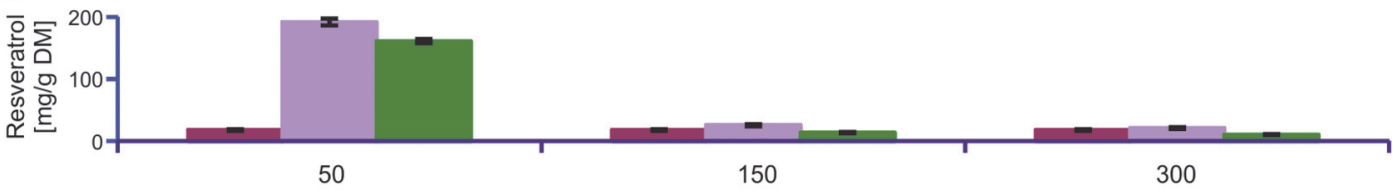

C

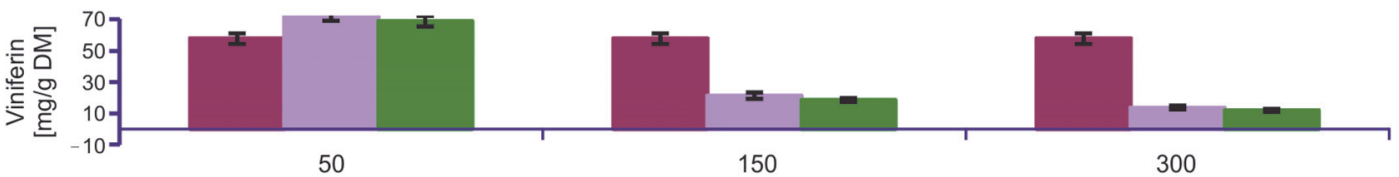

D

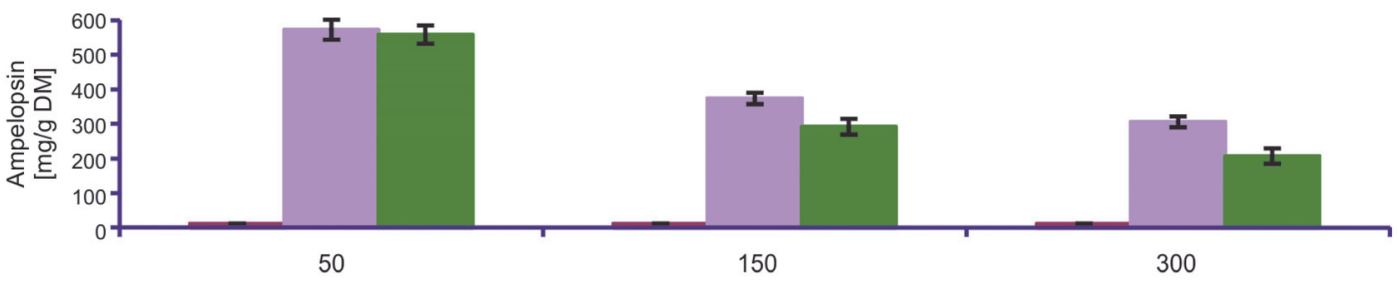

$\mathrm{E}$

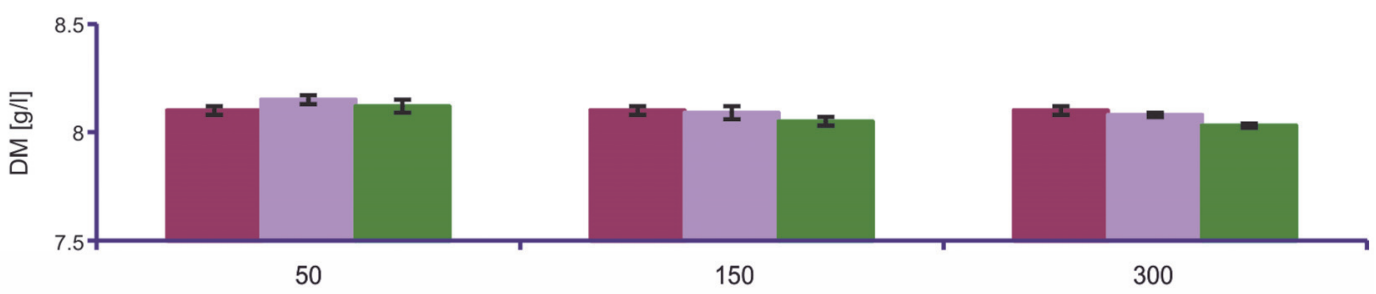

$\mathrm{F}$

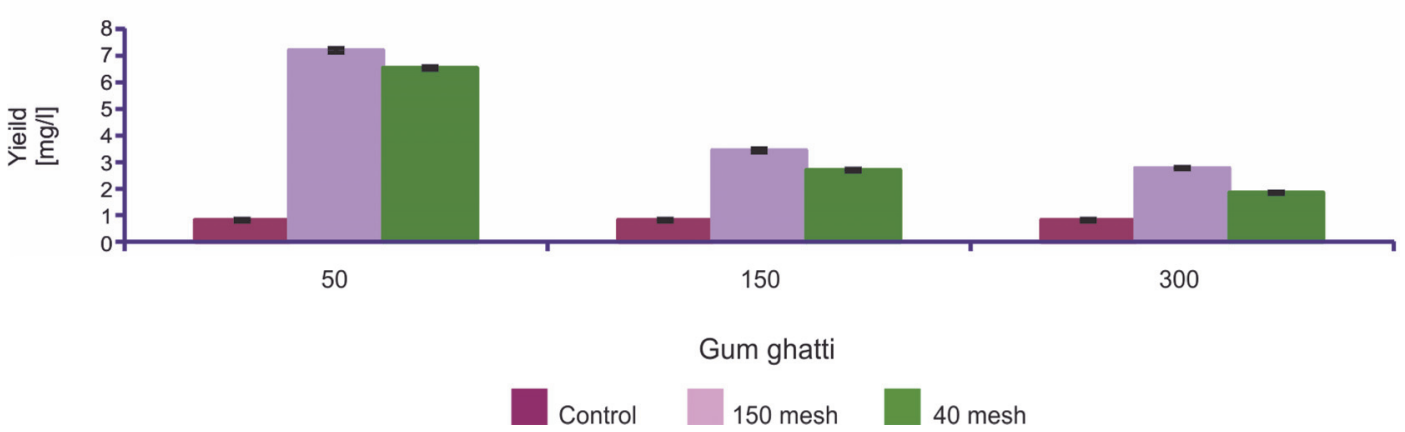

Fig. 2. Effect of varying concentration of gum ghatti when sieved through two different mesh sizes $(0.4 \mathrm{~mm}, 40 \mathrm{mesh}$ and $0.1 \mathrm{~mm}, 150 \mathrm{mesh}$ ) on stilbene production of A) piceid, B) resveratrol, C) viniferin, D) ampelopsin, E) total cell growth and F) total yield in $C$. trifolia cell cultures grown in $250 \mathrm{ml}$ flask, in growth medium 
decades on elicitor perception and transduction is now being combined with high-throughput methodologies such as transcriptomics and metabolomics to engineer plant cells that can produce compounds of interest at the industrial scale (Salehi et al., 2019). Thus, we conclude that diverse elicitors can promote higher accumulation of secondary metabolites in $C$. trifolia cell cultures.

\section{Acknowledgments}

Abhishek Joshi acknowledges the support of UGC, New Delhi, India, for the award of BSR meritorious fellowship [25-1/201415(BSR) 7-125/2007(BSR)] for conducting this work. Bhanupriya Kanthaliya acknowledges the support of DST, New Delhi, India, for the grant of a project (DST WOS A Scheme PD/OS/MoSTDST/B.Kanthaliya/CSA-7A (185)/ 2017-18/125).

\section{References}

Angelova Z., Georgiev S., Roos W. (2006) Elicitation of plants. Biotechnol. Biotechnol. Equip. 20(2): 72-83.

Arora J., Goyal S., Ramawat K.G. (2012) Co-evolution of pathogens, Mechanism involved in pathogenesis and biocontrol of plant diseases. [in:] Plant defence: biological control. Ed. Merillon J.M., Ramawat K.G. Doredrecht. Heidelberg Springer-Velarg: 3-22.

Arora J., Roat C., Goyal S., Ramawat K.G. (2009) High stilbenes accumulation in root cultures of Cayratiatrifolia (L.) Domin grown in shake flasks. Acta Physiol. Plant. 31: 1307-1312.

BaldiA., Srivastava A.K., Bisaria V.S. (2009) Fungal elicitors for enhanced production of secondary metabolites in plant cell suspension cultures. [in:] Symbiotic fungi, soil biology. Ed. Varma A., Kharkwal A.C. Berlin. Heidelberg SpringerVerlag: 373-380.

Dass S., Ramawat K.G. (2009) Elicitation of guggulsterone production in cell cultures of Commiphorawightii by plant gums. Plant Cell Tiss. Organ Cult. 96: 349-353.

Espinosa-Leal C.A., Puente-Garza C.A., García-Lara S. (2018) In vitro plant tissue culture: means for production of biological active compounds. Planta 248: 1-18.

Giri C.C., Zaheer M. (2016) Chemical elicitors versus secondary metabolite production in vitro using plant cell, tissue and organ cultures: recent trends and a sky eye view appraisal. Plant Cell Tiss. Organ Cult. 126: 1-18.

Goyal S., Lambert C., Cluzet S., Merillon J.M., Ramawat K.G. (2012) Secondary metabolites and plant defence. [in:] Plant defence: biological control. Ed. Merillon J.M., RamawatK.G. Doredrecht. Heidelberg Springer-Velarg: 109-138.

Goyal S., Ramawat K.G. (2008) Increased isoflavonoids accumulation in cell suspension culture of Pueraria tuberosa by elicitors. Indian J. Biotechnol. 7: 378-382.

He C., Hu Y., Yin Y., Tang C., Yin C. (2010) Effects of particle size and surface charge on cellular uptake and biodistribution of polymeric nanoparticles. Biomaterials 31 : 3657-3666.
Jain R., AnjaiahV., Babbar S.B. (2005) Guar gum: a cheap substitute for agar in microbial culture media. Lett. Appl. Microbiol. 41: 345-349.

Katiyar D., Hemantaranjan A., Singh B. (2015) Chitosan as a promising natural compound to enhance potential physiological responses in plant: a review. Indian J. Plant Physiol. 20: 1-9.

Kulkarni S.A., Feng S.S. (2013) Effects of particle size and surface modification on cellular uptake and biodistribution of polymeric nanoparticles for drug delivery. Pharma. Res. 30: 2512-2522.

Khan T., Khan T., Hano C., Abbasi B.H. (2019) Effects of chitosan and salicylic acid on the production of pharmacologically attractive secondary metabolites in callus cultures of Fagoniaindica. Ind. Crops Prod. 129: 525-535.

Kora A.J., Beedu S.R., Jayaraman A. (2012) Size-controlled green synthesis of silver nanoparticles mediated by gum ghatti (Anogeissuslatifolia) and its biological activity. Org. Med. Chem. Lett. 2: 17.

Krisa S., Larronde F., Budzinski H., Decendit A., Deffieux G., Merillon J.M. (1999) Stilbenes production by Vitisvinifera cell suspension cultures: methyl jasmonate induction and 13C biolabeling. J. Nat. Prod. 62: 1688-1690.

Liang C., Chen C., Zhou P., Xu L., Zhu J., Liang J., Zi J., Yu R. (2018) Effect of Aspergillus flavus fungal elicitor on the production of terpenoid indole alkaloids in Catharanthus roseus cambial meristematic cells. Molecules 23: 3276.

Lu F., Wu S.H., HungY., Mou C.Y. (2009) Size effect on cell uptake in well-suspended, uniform mesoporous silica nanoparticle. Small 1-6.

Müller K., Börger H. (1940) Experimentelle unter suchungenüber die Phytophtora-Resistenz der Kartoffel. Arb. Biol. Reichsanst Land Forstwirtsch. 23: 189-231.

Murashige T., Skoog F. (1962) A revised medium for rapid growth and bioassays with tobacco tissue culture. Physiol. Plant. 15: 473-497.

Naik P.M., Al-Khayri J.M. (2016) Abiotic and biotic elicitorsrole in secondary metabolites production through in vitro culture of medicinal plants. [in:] Abiotic and biotic stress in plants-recent advances and future perspectives. Ed. Shanker A., Shanker C., Intech Open: 247-277.

Pal A. (2008) Arabinogalactan protein and arabinogalactan: biomolecules with biotechnological and therapeutic potential. [in:] Biotechnology: bioactive molecules and medicinal plants. Ed. Merillon J.M., Ramawat K.G., Heidelberg, Springer-Verlag: 255-270.

Paxton J.D. (1981) Phytoalexins: a working redefinition. Phytopathol. Z. 101: 106-109.

Pezet R., Perret C., Jean-Denis J.B., Tabacchi R., Gindro K., Viret O. (2003) $\delta$-Viniferin, a resveratrol dehydrodimer: one of the major stilbenes synthesized by stressed grapevine leaves. J. Agric. Food Chem. 51(18): 5488-5492.

Ramirez-Estrada K., Vidal-Limon H., Hidalgo D., Moyano E., Golenioswki M., Cusidó R., Palazon J. (2016) Elicitation, an effective strategy for the biotechnological production of bioactive high-added value compounds in plant cell factories. Molecules 21: 182. 
Roat C., Ramawat K.G. (2009a) Elicitor-induced accumulation of stilbenes in cell suspension cultures of Cayratiatrifolia (L.). Domin. Plant Biotech. Rep. 3: 135-138.

Roat C., Ramawat K.G. (2009b) Morphactin and 2iP markedly enhance accumulation of stilbenes in cell cultures of Cayratiatrifolia (L.). Domin. Acta Physiol. Plant. 31: 411-414.

Saigne-Soulard C., Abdelli-Belhadj A.,Telef-Micouleau M., Bouscaut J., Cluzet S., Corio-Costet M.F., Merillon J.M. (2015) Oligosaccharides from Botrytis cinerea and elicitation of grapevine defense. [in:] Polysaccharides. Ed. Ramawat K.G., Merillon J.M., Switzerland, Springer International Publishing: 939-958.

Salehi M., Moieni A., Safaie N., Farhadi S. (2018) Elicitors derived from endophytic fungi Chaetomium globosum and Paraconiothyrium brasiliense enhance paclitaxel production in Corylus avellana cell suspension culture. Plant Cell Tis. Organ. Cult. 136: 161-171.

Salehi M., Karimzadeh G., Naghavi M.R. (2019) Synergistic effect of coronatine and sorbitol on artemisinin productionin cell suspension culture of Artemisia annua L. cv. Anamed. Plant Cell Tis. Organ. Cult. 137: 587-597.

Sarmadi M., Karimi N., Palazón J., Ghassempour A., Mirjalili M.H. (2018) The effects of salicylic acid and glucose on biochemical traits and taxane production in a Taxusbaccata callus culture. Plant Physiol. Biochem. 132: 271-280.

Sharma A., Mathur A.K., Ganpathy J., Joshi B., Patel P. (2019) Effect of abiotic elicitation and pathway precursors feeding over terpenoid indole alkaloids production in multiple shoot and callus cultures of Catharanthusroseus. Biologia 74: 543-553.

Shasmita, Singh N. R.,RathS.K.,Behera S., Naik S.K. (2018) In vitro secondary metabolite production through fungal elicitation: an approach for sustainability. [in:] Fungal nanobionics: principles and applications. Ed. R. Prasad et al. Singapore, Springer: 215-242.
Silpa P., Roopa K., Thomas T.D. (2018) Production of plant secondary metabolites: current status and future prospects. [in:] Biotechnological approaches for medicinal and aromatic plants. Singapore, Springer: 3-25.

Tashackori H., Sharifi M., Chashmi N.A., Fuss E., Behmanesh M., Safaie N. (2019) RNAi-mediated silencing of pinoresinollariciresinol reductase in Linum album hairy roots alters the phenolic accumulation in response to fungal elicitor. J. Plant Physiol. 232: 115-126.

Vidal-Limon H., Sanchez-Muñoz R., Khojasteh A., Moyano E., Cusido R.M., Palazon J. (2016) Taxus cell cultures, an effective biotechnological tool to enhance and gain new biosynthetic insights into taxane production. Biopro. Plant In Vitro Sys. 1-23.

Winkler A., Jose D.N., Inmaculada A., César P.C., Katrina R., Shauna S., Marta B.L. (2017) Short-chain chitin oligomers: promoters of plant growth. Marine drugs. 15: 40.

Xu H., Li J., Wang S., Xu L., Cheng R., Zhang J. (2017) Oligosaccharide elicitor prepared from Salecan triggers the defense responses of Arabidopsis thaliana ColO against Botrytis cinerea infection. World J. Microbiol. Biotechnol. 33: 165.

Yu L.J., Lan W.Z., Qin W.M, Jin W.W., Xu H.B. (2002) Oxidative stress and taxol production induced by fungal elicitor in cell suspension cultures of Taxuschinensis. Biol. Plant. 5: 459-461.

Zhai X., Jia M., Chen L., Zheng C.J., Rahman K., Han T., Qin L.P. (2017) The regulatory mechanism of fungal elicitorinduced secondary metabolite biosynthesis in medical plants. Crit. Rev. Microbiol. 43: 238-261.

Zhao J., Davis L.C., VerpoorteR. (2005) Elicitor signal transduction leading to production of plant secondary metabolites. Biotech. Adv. 23: 283-333.

Zheng M., Yu J. (2016) The effect of particle shape and size on cellular uptake. Drug Deliv. Transl. Res. 6(1): 67-72. 